\title{
Characterization of Resident Glomerular Cells in the Rat Expressing Ia Determinants and Manifesting Genetically Restricted Interactions with Lymphocytes
}

\author{
George F. Schreiner, Jeanne-Marie Kiely, Ramzi S. Cotran, and \\ EmIL R. UnANue, Departments of Pathology, Harvard Medical School and \\ Brigham and Women's Hospital, Boston, Massachusetts 02115
}

\begin{abstract}
A B S T R A C T The existence of a subpopulation of rat glomerular cells bearing Ia determinants has been demonstrated with the aid of techniques for the enzymatic isolation and culture of glomerular cells. The Ia-positive cell is normally resident in the uninflamed glomerulus. It resembles a mononuclear phagocyte and consists of a functionally heterogeneous cell population with the capacity of $\mathrm{Fc}$ receptor display and phagocytosis, both in vivo and in vitro. A new technique for labeling these cells in situ in intact glomeruli has indicated that Ia-positive cells make up $\sim 2 \%$ of the total glomerular cell population. The isolated glomerular cells can take up antigen and stimulate immune lymphocytes in an I-region-restricted interaction. They are strongly stimulatory in an allogeneic primary mixed lymphocyte culture. Characterization of this cell type suggests potential new insights into the pathogenesis of renal allograft rejection and immunologically mediated glomerulonephritis.
\end{abstract}

\section{INTRODUCTION}

Many studies over the last three decades established the pathogenesis of glomerulonephritis as arising from the presence of antibody in the kidney in either of two forms: either deposited as an immune complex formed in a systemic immune reaction or as an antibody directed against glomerular antigenic determinants themselves. Both situations initiate humoral events including the activation of complement that result in functional impairment of glomerular filtration (1). The role of circulating leukocytes became established with the demonstration that neutrophils contributed to the early phase of glomerular damage in experimental glomerulonephritis (2). Recently, we have shown that

Received for publication 13 April 1981 and in revised form 8 June 1981. some forms of experimental glomerulonephritis are associated with an influx of monocytes that correlates with sustained histological and functional abnormalities in the glomerulus (3). Such investigations have visualized the glomerulus as a somewhat passive participant in its own impairment, providing a vulnerable milieu for a stereotyped inflammatory response whose only reference to the kidney was as an antibody depot. We have now made observations that suggest that the kidney may be a more active contributor to glomerular immune reactions than previously realized.

Using techniques for the isolation and short-term culture of glomerular cells, and their in situ labeling, we have found a new cell intrinsic to the uninflamed renal glomerulus. It is phagocytic and bears I-regionassociated antigens (Ia), the membrane proteins coded for by the major histocompatibility locus that permit specific interactions between phagocytes and lymphocytes. This Ia-bearing glomerular cell can present antigen in a genetically restricted fashion to syngeneic lymphocytes and can selectively stimulate allogeneic lymphocytes. The presence of this cell indicates that the glomerulus has the potential to process antigen actively and to initiate a cellular immune response in situ. These observations not only bear significant implications for defining a new pathogenesis of glomerulonephritis, they also suggest a better way of understanding the mechanisms that underlie the initiation of host rejection of kidney transplants.

\section{METHODS}

Animals. Female rats, either of the Lewis or the Buffalo strains, weighing 100-175 g, and at least 5 wk old, were obtained from Microbiological Associates (Walkersville, Md.).

Glomerular isolation. Before harvesting glomeruli, both kidneys were thoroughly perfused to remove circulating erythrocytes and leukocytes with a technique modified from Griffith et al. (4), with the additional step of opening the left renal vein to permit the perfusate to drain. $50-100 \mathrm{ml}$ of a $0.9 \% \mathrm{NaCl}$ solution injected via the aorta into both kidneys 
produced their complete blanching and eventually a clear perfusate. Mottled kidneys, indicative of incomplete perfusion, were discarded. Possible blood contamination was judged minimal because erythrocytes or neutrophils were rare in isolated glomeruli as well as in cultures of enzymatically isolated glomerular cells. Glomeruli were obtained by pressing slices of renal cortex through graded sieves (Tyler sieves, Curtin Matheson Scientific, Inc., Houston, Tex.) of 250,150 , and $75 \mu \mathrm{g}$ with a rubber stopper (5). Preparations consisted of $90-95 \%$ glomeruli with occasional contaminating tubular fragments.

The protocol for the enzymatic release of glomerular cells was extensively modified from previous reports (6). The purified glomeruli were washed twice in Hanks' balanced salt solution (HBSS) ${ }^{1}$ at $50 \mathrm{~g}$ and then placed, in step 1 , in a solution consisting of trypsin (Type III, 10,200 BAEE U/mg) (Sigma Chemical Co., St. Louis, Mo.), $1 \mathrm{mg} / \mathrm{ml}$; collagenase (Type CLS IV, 126 U/mg) (Millipore Corp., Freehold, N. J.), $1 \mathrm{mg} / \mathrm{ml}$; and DNAase (Type III, $1,825 \mathrm{Kunitz} \mathrm{U} / \mathrm{mg}$ ), $0.01 \mathrm{mg} / \mathrm{ml}, \mathrm{pH} 7.2-7.4$, for $45 \mathrm{~min}$ at $37^{\circ} \mathrm{C}$ on a rocking platform. The partially digested glomeruli were then washed in HBSS lacking calcium or magnesium (Microbiological Associates) and placed, in step 2 , in a solution of 2 mM EDTA (Sigma Chemical Co.) in HBSS without calcium or magnesium for $10 \mathrm{~min}$ at $37^{\circ} \mathrm{C}$. This preparation was then centrifuged at $50 \mathrm{~g}$ for $10 \mathrm{~min}$ and divided into a sediment and a suspension of single cells. In step 3 , the sediment, consisting of partially digested glomerular fragments, was incubated for an additional $20 \mathrm{~min}$ at $37^{\circ} \mathrm{C}$ in collagenase, $2 \mathrm{mg} / \mathrm{ml}$. The preparation was allowed to settle for $90 \mathrm{~s}$ at $1 \mathrm{~g}$, which removed most of the residual debris. The supernate after the collagenase incubation was then centrifuged at $400 \mathrm{~g}$, washed, and recombined with the cells removed after step 2 . Cells were spun at $400 \mathrm{~g}$ for $10 \mathrm{~min}$ and resuspended in HBSS with $1 \%$ bovine albumin (Sigma Chemical Co.) and $1 \mathrm{mM}$ Hepes buffer (Microbiological Associates). This process resulted in a suspension containing between 2 and $5 \times 10^{6}$ single cells per rat.

Cell adherence and labeling of Ia antigens. $1 \mathrm{ml}$ of cells at $2 \times 10^{6} / \mathrm{ml}$ was placed in flat-bottom 16- $\mathrm{mm}$ wells of multiwell trays (Falcon Labware, Div. of Becton-Dickinson \& Co., Oxnard, Calif.) containing glass round coverslips (Bellco Glass, Inc., Vineland, N. J.) previously coated with heatdecomplemented fetal calf serum (Microbiological Associates). The cells were allowed to settle onto the plate by incubation at $37^{\circ} \mathrm{C}$ for $2 \mathrm{~h}$ in a tissue culture incubation chamber containing $5 \% \mathrm{CO}_{2}$ and then used in different experiments. The medium during adherence was the same used for the antigen presentation assay. In some experiments, cells were cultured for longer periods, as specified in the text.

Labeling of rat Ia antigens was done with pooled batches of monoclonal antibody (Accurate Chemical \& Scientific Corp., Hicksville, N. Y.). Two preparations previously studied in detail $(7,8)$ were used: (a) MASO29B, a mouse IgG from clone OX3HL that binds to Ia antigens from Lewis (RT1 haplotype l) and Wistar (haplotype u) strains, that cross-reacts with mouse Ia specificity 9; and (b) MASO28B, a mouse IgG from clone OX4HL that recognizes a common Ia determinant of all rats and cross-reacts with mouse Ia specificity 18 . Using our staining protocol, we confirmed that MASO28B recognizes the $I$ region of mouse haplotypes $b$ and $s$ by positively labeling a percentage of peritoneal macrophages from $\mathrm{C} 57 \mathrm{BL} / 6$ and

${ }^{1}$ Abbreviations used in this paper: EA, erythrocyte antisera; FITC-anti-Ig, fluorescein-labeled $\mathrm{F}(\mathrm{ab})_{2}$ rabbit antimouse IgG; HBSS, Hanks' balanced salt solution; PBS, phosphate-buffered saline.
A.TH strains; staining of A.TL and B10.D2 cells was negative. Similarly, MASO29B recognizes mouse haplotypes $\mathbf{s}$ and $\mathbf{k}$ in that it labels macrophages from A.TH and A.TL strains but not C57BL/6 or B10.D2 strains. We also confirmed McMaster and Williams' (8) findings that, in the rat, both antisera label $20-40 \%$ of adherent splenic macrophages, all B lymphocytes, and no peripheral $\mathrm{T}$ cells. We also found that each preparation labeled 5-10\% of peritoneal exudate cells similar to the level of Ia expression noted in the mouse (9). Labeling was carried out with a 1:4 dilution of decomplemented, pooled (1:1) batches of MASO28B and MASO29B, diluted in HBSS Coverslips containing the glomerular cells were placed faceside up in new wells to which were added $300 \mu$ l of the anti-Ia monoclonal antibodies. They were incubated for 20 min at either $4^{\circ}$ or $20^{\circ} \mathrm{C}$, depending upon the protocol; the coverslips were then dipped in three washes of cold phosphate-buffered saline (PBS) and placed into fresh wells to which was added a solution of fluorescein-labeled $F(a b)_{2}$ rabbit anti-mouse IgG (FITC-anti-Ig) at $100 \mu \mathrm{g} / \mathrm{ml}$ (10). After incubation at $4^{\circ} \mathrm{C}$ or room temperature for an additional $20 \mathrm{~min}$, the coverslips were rinsed in two washes of saline and then fixed in $2 \%$ paraformaldehyde. The cells were then read for presence of fluorescence on a Leitz microscope with appropriate filters (E. Leitz, Inc., Rockleigh, N. J.). Unless otherwise detailed, results were expressed as percentage of positive labeled cells, for Ia, of total adherent cell population. Controls of labeling with normal mouse IgG or with electrophoretically purified mouse IgG from the plasmacytoma line MOPC195 (Litton Bionetics, Div. Litton Industries, Inc., Kensington, Md.) instead of anti-Ia antibody did not disclose any staining. In some experiments, total cell suspensions, before adherence, were labeled for Ia antigens. $2 \times 10^{6}$ cells were suspended in $300 \mu \mathrm{l}$ of anti-Ig (1:4, as above) for 20 min at $4^{\circ} \mathrm{C}$, washed twice, and then placed in FITC-anti-Ig, as above, for $20 \mathrm{~min}$ at $4^{\circ} \mathrm{C}$. The cells were then washed and fixed in $2 \%$ paraformaldehyde. Cells were scored for fluorescent labeling and reported as a percentage of total single cells in suspension. Cells in clumps were not scored. In some experiments, monocytes were obtained by enrichment on Ficoll-Hypaque gradients after subjecting peripheral blood to dextran sedimentation. After adherence for $2 \mathrm{~h}$ on coverslips, they were labeled as above. Control experiments indicated that treatment of cells that express Ia, such as monocytes and macrophages, with trypsin and collagenase, as was done to the glomerular cells, neither induced the expression of Ia nor affected the Ia already found on their surfaces.

Labeling intact glomeruli. Whole glomeruli, isolated as noted above, were placed in a solution containing $1 \mathrm{mg} / \mathrm{ml}$ trypsin and $0.01 \mathrm{mg} / \mathrm{ml}$ DNAase for $30 \mathrm{~min}$ at $37^{\circ} \mathrm{C}$ in HBSS, pH 7.2. The glomeruli were then washed twice and incubated first in a 1:4 dilution of pooled anti-Ia antisera for $30 \mathrm{~min}$ at $4^{\circ} \mathrm{C}$, washed twice, and then incubated in $100 \mu \mathrm{g} / \mathrm{ml}$ of FITCanti-Ig for an additional $30 \mathrm{~min}$ at $4^{\circ} \mathrm{C}$. After washing two further times, the whole but partially digested glomeruli were then fixed in $2 \%$ paraformaldehyde and examined microscopically. Controls included: $(a)$ deleting preincubation with trypsin, (b) deleting incubation with anti-Ia but labeling with FITC-anti-Ig, and $(c)$ substituting for anti-Ia antibody an equal concentration of mouse IgG from plasmacytoma line MOPC195, as detailed above. In none of the controls in any experiment did we observe labeling of any glomerular cells.

Latex bead ingestion. $40 \times 10^{6}$ latex beads ( $1 \mu \mathrm{m}$; Dow Diagnostics, Indianapolis, Ind.) were layered onto the culture wells, which were spun at $150 \mathrm{~g}$ for $5 \mathrm{~min}$ and then incubated at $37^{\circ} \mathrm{C}$ for $45 \mathrm{~min}$. The coverslips were washed with warm PBS to remove unbound latex and fixed in $2 \%$ paraformaldehyde in PBS. Some coverslips were subsequently studied for 
the presence of Ia-determinants or for Fc receptors. Cells interiorizing three or more particles were scored as positive.

Fc receptor. Receptors for Fc moiety of $\mathrm{IgG}$ were assayed by using sheep erythrocytes coated with IgG rabbit antierythrocyte antisera (EA), as previously described (11). $1 \mathrm{ml}$ of a 1:100 dilution of the 2\% EA solution was layered onto the adherent cells. The tissue culture plates were spun for 5 min at $150 \mathrm{~g}$ to sediment the EA onto the adherent cells. After further incubation at room temperature for $5 \mathrm{~min}$, an equal volume of $1.25 \%$ glutaraldehyde in PBS was gently added to the wells. Preparations labeled for the presence of both Fc receptors and Ia determinants were labeled with anti-Ia antiserum for $20 \mathrm{~min}$ at room temperature before fixation for $10 \mathrm{~min}$ in glutaraldehyde, washed four times in PBS, and then labeled with FITC-anti-Ig.

In vivo phagocytosis. Four 150-g Lewis rats were injected with $8 \mathrm{mg}$ of rhodamine-conjugated heat-aggregated human gamma globulin (Miles Laboratories, Inc., Elkhart, Ind.) and the glomeruli harvested $90 \mathrm{~min}$ after injection. Individual glomerular cells were prepared and evaluated for the presence of red fluorescent phagocytic vacuoles, which indicate the ingestion of rhodamine-labeled gamma globulin before sacrifice, and green fluorescent membrane staining indicating the presence of labeled Ia determinants, or both.

Antigen presentation assay. The proliferation of immune $\mathrm{T}$ lymphocytes in response to antigen presentation by Iabearing cells was carried out in a protocol analogous to that previously described for mice (11). Immune lymphocytes were obtained by injecting female Lewis rats, 2 mo old, with $2 \times 10^{5}$ live Listeria monocytogenes into the peritoneum $10 \mathrm{~d}$ before harvesting. $3 \mathrm{~d}$ before harvesting each rat received $5 \mathrm{ml}$ i.p. of $10 \%$ proteose-peptone (Difco Laboratories, Detroit, Mich.). T lymphocytes were separated from adherent peritoneal exudate cells by two cycles of $2 \mathrm{~h}$ of adherence on plastic tissue culture dishes, followed by a third cycle of adherence in overnight culture. Glomerular cells at $2 \times 10^{6}$ cells $/ \mathrm{ml}$ were allowed to adhere according to the labeling protocol. Heat-killed, opsonized Listeria $\left(2 \times 10^{7}\right)$ were added to the cultures of $2 \times 10^{6}$ adherent glomerular cells and centrifuged at $400 \mathrm{~g}$ for $5 \mathrm{~min}$ to enhance settling of Listeria onto the cells. The antibody-coated Listeria were prepared by incubating heat-killed Listeria, $5 \times 10^{7} / \mathrm{ml}$, in a $1: 10$ dilution of whole rabbit anti-Listeria serum. The Listeria-pulsed cells were incubated at $37^{\circ} \mathrm{C}$ for $1 \mathrm{~h}$, washed thoroughly, and then mixed with $4 \times 10^{5}$ immune $T$ cells in medium consisting of RPMI 1640 with $10 \%$ fetal calf serum, $1 \%$ penicillinstreptomycin, $1 \mathrm{mM}$ Hepes buffer, $1 \mathrm{mM}$ pyruvate, and $1 \mathrm{mM}$ L-glutamine (Gibco Laboratories, Grand Island Biological Co., Grand Island, N. Y.). Total length of the co-cultures was $4 \mathrm{~d}$. Cultures were pulsed with $0.4 \mathrm{mCi}$ of tritiated thymidine (sp act $20 \mu \mathrm{Ci} / \mathrm{ml}$, New England Nuclear, Boston, Mass.) over the last $16 \mathrm{~h}$ of culture. Proliferation was assayed by the incorporation of $\left[\mathrm{H}^{3}\right]$ thymidine into trichloracetic-insoluble material. As has been noted previously, the growth of $T$ cells requires Ia-bearing accessory cells and Ia homology between reacting $T$ cells and antigen-presenting macrophages (11).

Assay of allogeneic reactivity. The responder cells were lymphocytes isolated from the axillary, periaortic, popliteal, and inguinal lymph nodes of adult female Buffalo rats. The stimulatory cells consisted of $(a)$ spleen cells from allogeneic Lewis female rats, $(b)$ adherent glomerular cells from Lewis rats, or $(c)$ syngeneic adherent glomerular cells from Buffalo strain female rats. The medium was the same as for antigen presentation, with the addition of $50 \mu \mathrm{M} 2$-mercaptoethanol. Stimulator cells were placed in culture at a concentration of $2 \times 10^{5} / \mathrm{ml}(1 \mathrm{ml} /$ well $)$ for spleen cells and $5 \times 10^{5}$ cells $/ \mathrm{ml}$ for glomerular cells. Stimulator cells were allowed to adhere for $2 \mathrm{~h}$ on flat-bottomed microwells, washed, and then irradiated with $1,500 \mathrm{rad}$. The responder lymphocytes $\left(2 \times 10^{5}\right)$ were then added and the cultures allowed to proceed for $6 \mathrm{~d}$. Proliferation was assayed exactly as above in the antigen presentation assay by adding tritiated thymidine to the cultures $16 \mathrm{~h}$ before harvest on day 6 .

\section{RESULTS}

Identification of Ia-positive cells in glomeruli. Our interest in the possible existence of a resident, antigenprocessing cell in the glomerulus led to the following experiments, in which enzymatically isolated glomerular cells were fluorescently stained for the presence of rat Ia antigens. Cells were examined in suspension and after varying times of adherence on coverslips. As shown in four representative experiments in Table I, we consistently found between 6 and $8 \%$ of total glomerular cells, in a single-cell suspension, bearing Ia antigens. Allowing the cells to adhere on coverslips for $2 \mathrm{~h}$ enriched the Ia-positive population three- to sixfold to between 21 and $37 \%$ of the total adherent glomerular cell population. About $1 \%$ of the nonadherent cells were Ia-positive. We found that, after $2 \mathrm{~h}$ of culture and after Ia labeling, only $\sim 30-40 \%$ of the total cell population remain adherent.

$24 \mathrm{~h}$ of in vitro culture resulted in a small and variable decrease in the percentage of Ia-bearing cells, as seen in Table I. This appears to be partly a dilutional effect, in that there are always more cells per highpower field after $24 \mathrm{~h}$ in culture than after $2 \mathrm{~h}$. It appears that Ia-negative cells are less adherent in shortterm culture and more susceptible to being dislodged; after $24 \mathrm{~h}$, they are more adherent. For example, the mean number of cells per high-power field ( 25 fields) in experiment No. 4 was 29.7 at $2 \mathrm{~h}$, rising to 47.2 at

TABLE I

Ia-positive Glomerular Cells in Culture

\begin{tabular}{cccc}
\hline $\begin{array}{c}\text { Experiment } \\
\text { No. }\end{array}$ & $\begin{array}{c}\text { Initial } \\
\text { suspension }\end{array}$ & $\begin{array}{c}2-\mathrm{H} \\
\text { adherence }\end{array}$ & $\begin{array}{c}\text { 24-H } \\
\text { adherence }\end{array}$ \\
\hline & & $\%$ & \\
1 & 6 & 37 & 21 \\
2 & 7 & 21 & 14 \\
3 & 8 & 23 & 18 \\
4 & 6.5 & 31 & 17
\end{tabular}

In each experiment, glomerular cells were labeled for the presence of Ia determinants at three time periods. "Initial suspension" refers to the percentage of Ia-positive cells in the total glomerular cell population at the beginning of the cultures, before adherence. The figures in the 2-h and 24-h columns refer to the percentage of adherent glomerular cells that were positively labeled for Ia after 2 or $24 \mathrm{~h}$ of culture on coverslips. 200-300 cells in each category were counted. 
$24 \mathrm{~h}$. Nonetheless, there is also an absolute decrease in maintenance of Ia determinants that becomes prominent during more prolonged in vitro culture (see below).

Fig. 1A shows a typical Ia-positive glomerular cell. Morphologically, it resembles a mononuclear phagocyte. It ranges between 15 and $25 \mu \mathrm{m}$ in diameter. It can be ameboid in appearance but more typically is oval while adherent, with the nucleus asymmetrically placed. The cytoplasm contains few vacuoles. The Ia antigens are diffusely distributed. It should be noted that there is an apparently identical population of cells, with very similar membrane receptors but lacking Ia antigens.

Other cell types are present in the heterogeneous population of adherent cells. The predominant cell type is a smaller $(10-15 \mu \mathrm{m})$ Ia-negative cell, seen in Fig. 1B, which is an endothelial cell by electron microscopy. ${ }^{2}$ Adherent, large epithelial cells, 40-60 $\mu \mathrm{m}$ in diameter, are prominent in the 2-h cultures, less so after $24 \mathrm{~h}$ (Fig. 1C). They are notable for an abundant cytoplasm, ruffled membranes, and numerous vacuoles. Also present in variable numbers are contaminating tubular epithelial cells, as determined by electron microscopy. ${ }^{2}$ Fig. 1D shows an additional cell type present in all cultures that closely resembles the contractile glomerular cell lines described by Ausiello et al. (12). In early culture, it is intermediate in size but quickly elongates with spreading, spindly processes. These cells do not bear Ia determinants and may be of mesangial origin (12).

Functional properties of Ia-positive cells. We assayed three properties of Ia-positive cells: $(a)$ in vitro and in vivo phagocytosis, $(b)$ in vitro display of $F c$ receptors, and $(c)$ maintenance of the Ia phenotype in culture.

Table II shows representative experiments in which isolated adherent glomerular cells were scored for phagocytosis of latex beads and the presence of Ia antigens. In both experiments, 17 and $18 \%$ of adherent glomerular cell population manifested phagocytic capability of which 60 and $54 \%$ were Ia-positive. Similarly, glomerular cells were scored for the display of $F_{c}$ receptors and of Ia antigens. Again, in Table II, $\sim 40 \%$ of adherent glomerular cells were $\mathrm{Fc}$ receptor positive, of which approximately one-third were Iapositive.

The above data refer to assays done after $2 \mathrm{~h}$ of culture. In evaluating Ia-positive cells both after $2 \mathrm{~h}$ and after $24 \mathrm{~h}$, it became clear that there was heterogeneity among Ia-bearing cells with respect to

\footnotetext{
${ }^{2}$ G. F. Schreiner, R. S. Cotran, and E. R. Unanue. Ultrastructural analysis of glomerular Ia-positive cells. Manuscript in preparation.
}

the expression of one or the other property and that there was a shift in their differential capacities over time in culture. Fig. 2 demonstrates one of two experiments in which Ia-positive cells were scored for phagocytosis and $\mathrm{Fc}_{\mathrm{c}}$ receptors at $2 \mathrm{~h}$ and at $24 \mathrm{~h}$. Ia-positive cells were divided into four categories: $(a)$ Fc-receptor negative, latex-phagocytosis negative; $(b)$ Fc-receptor negative, latex-phagocytosis positive; $(c)$ Fc-receptor positive, latex-phagocytosis negative; and $(d)$ positive for both $F c$ receptor and latex phagocytosis. $30 \%$ of the Ia-positive cells at $2 \mathrm{~h}$ displayed neither phagocytosis nor Fc receptors; this decreased to $<20 \%$ over $24 \mathrm{~h}$. $23 \%$ of the Ia-positive cells manifested only phagocytosis, with only a modest decrement with time. The largest shifts were seen in Ia-positive cells that also bore Fc receptors. Those cells expressing only Fc receptors decreased from 30 to $10 \%$ in longer culture. Ia-positive cells expressing both $\mathrm{Fc}$ receptors and phagocytosis increased from 18 to $51 \%$ of the Ia-bearing population. In this experiment, the percentage of total adherent cells that were Ia-positive was $34 \%$ at $2 \mathrm{~h}$ and $13 \%$ at $24 \mathrm{~h}$. The mean number of cells per high-power field (25 fields) was 29 at $2 \mathrm{~h}$ and 40 at $24 \mathrm{~h}$, which indicates increased adherence of all glomerular cells as discussed above. Thus, within the cells continuing to display Ia antigens there is a shift in functional properties towards a more active state, i.e., with increasing numbers of cells displaying both Fc receptors and phagocytic activity, and fewer cells displaying only one property or neither. We also noted that the range of bead ingestion increased from 2-5 to 5-10 beads/cell after prolonged culture (Fig. 3A). The number of EA bound per cell increased from $3-5$ to $>10 /$ cell, which indicates an increase in the number or the avidity of $\mathrm{Fc}$ receptors or both (Figs. $3 B$ and $C$ ).

There is an absolute decrease in the percentage of Ia-positive cells in prolonged culture, whereas the number of cells per high-power field is relatively constant. This is demonstrated in Fig. 4; in this experiment, by $96 \mathrm{~h}$ of in vitro culture, only $4 \%$ of the total glomerular cell population remained Ia-positive. In addition, the intensity of Ia labeling decreases with time among the positive cells, which indicates a generalized progressive loss of Ia antigens. The loss of the Ia phenotype by cells under prolonged culture conditions has been observed in the mouse $(13,14)$.

Finally, it should be noted that neither the small endothelial cells nor the larger epithelial cells nor the elongated cells of Fig. 1D have been observed to display $F_{c}$ receptors or to ingest latex particles at any time in culture. Whereas those properties are expressed as a percentage of the total glomerular cell population, only the intermediate-sized cell described above is positive in these assays.

Controls and identification of Ia-positive cells as 

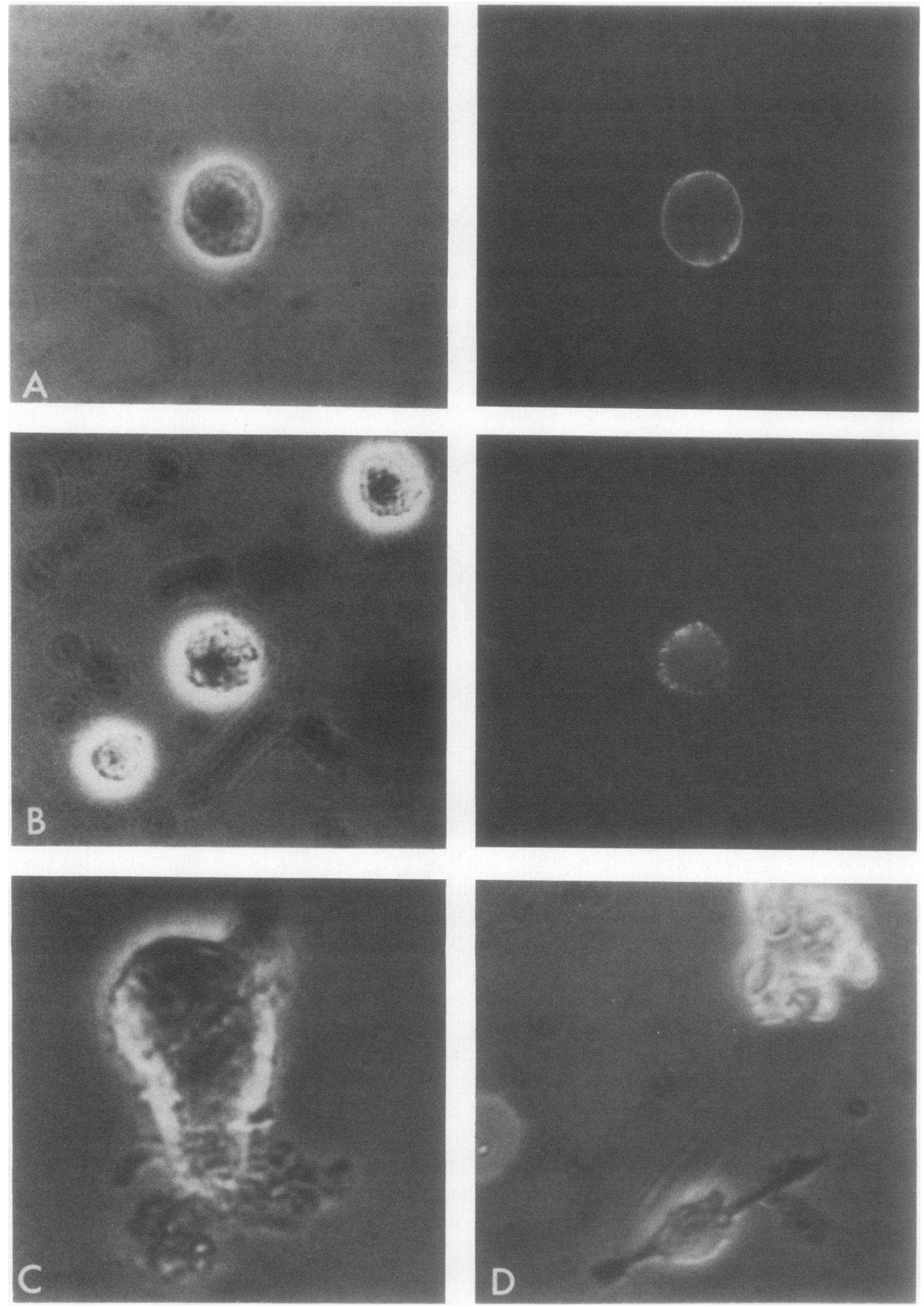

FIGURE 1 Labeling of Ia determinants on adherent glomerular cells. (A) Phase contrast and fluorescent micrographs of an Ia-positive, adherent glomerular cell after $24 \mathrm{~h}$ of culture, $\times 480$. (B) An adherent, Ia-positive glomerular cell with an adjacent, smaller, Ia negative cell (in experiments in progress, electron microcropic analyses have shown that this small Ia-negative cell is the endothelial cell ${ }^{2}$ ). In the upper right corner is an intermediate-size Ia-negative cell, $\times 480$. (C) A large epithelial cell in $2 \mathrm{~h}$ culture, $\times 550$. (D) An elongated, Ia-negative, adherent glomerular cell with spindle processes, morphologically resembling contractile mesangial cells (12). The other cell in the upper right corner has bound EA and thus displays Fc receptors, $\times 480$. 
TABLE II

Functional Properties of Adherent Glomerular Cells

\begin{tabular}{cccc}
\hline $\begin{array}{c}\text { Experiment } \\
\text { No. }\end{array}$ & Phagocytic & $\begin{array}{c}\text { Fc receptor- } \\
\text { positive }\end{array}$ & Ia-Positive \\
\hline & & $\%$ & \\
1 & $18(54)^{*}$ & - & 37 \\
2 & $17(60)$ & - & 21 \\
3 & - & $42(28) \ddagger$ & 34 \\
4 & - & $44(33)$ & 24
\end{tabular}

"Phagocytic" refers to the percentage of adherent glomerular cells, after $2 \mathrm{~h}$ of culture, ingesting three or more polystyrene beads. "Fc receptor positive" refers to the percentage of total adherent glomerular cells displaying Fc receptors under similar conditions. Positive cells were those binding three or more opsonized erythrocytes (EA). "Ia-positive" refers to percentage of total adherent glomerular cells positively labeled for Ia determinants after $2 \mathrm{~h}$ in culture. Experiments 1 and 2 studied the uptake of beads and surface Ia; experiments 3 and 4 studied Fc receptors and surface Ia. 200 cells in each category were counted.

* Numbers in parentheses refer to percentage of phagocytic cells that were also Ia-positive.

$\ddagger$ Numbers in parentheses refer to percentage of Fc receptorpositive cells that were also Ia-positive.

glomerular cells. Clearly, a major question at this point is whether this cell type is a contaminating blood element or an extraglomerular renal cell. We have developed several approaches to this question and believe, on their basis, that these are specifically glomerular cells.

First, the kidneys were thoroughly perfused with saline with complete blanching before the glomeruli were harvested. This minimized blood contamination, as supported by the fact that erythrocytes were not observed in isolated glomeruli and were quite rare in the dispersed cell preparations, making up much less than $1 \%$ of the total cell population before adherence.

The possibility that the Ia-positive cells were interstitial or bound to the tubules that occasionally contaminate the preparation was examined in two ways. We subjected tubular-enriched fragments from sieve sizes other than the ones used to harvest the glomeruli or interstitial fragments to the same enzymatic digestion. This yielded few adherent cells and no Ia-positive cells. Therefore, the Ia-positive cells appeared only in glomerular-enriched fractions. If Iapositive cells reside in the tubules, these are not detached under our experimental conditions.

More pointedly, we have developed a technique for labeling these cells in situ in intact glomeruli. It is based on our observations that trypsin made the glomeruli permeable under appropriate conditions, permitting antibody to diffuse in and bind to trypsinresistant antigens, while not grossly disturbing the cytoarchitecture of the intact glomerulus. The results are shown in Figs. 5A and B, in which Ia-positive cells are revealed in the normal glomerulus. They are primarily in an axial distribution with scattered cells located more peripherally. Figs. 5C and D show increased magnification of two glomeruli revealing elongated, serpiginous Ia-bearing cells, as well as the more oval-type cells seen in culture. The average number of cells per glomerulus is 10.2 , with considerable heterogeneity between glomeruli, the range being between 5 and 20 cells/glomerulus. Control experiments using a nonspecific myeloma IgG preparation instead of the anti-Ia antisera showed no cellular staining but only a very weak, generalized background fluorescence.

Finally, we have compared the percentage of Iapositive cells in the adherent glomerular cell population with that in adherent monocyte populations. In three experiments, the percentage of Ia-bearing monocytes was $0.5,0$, and $2 \%$. In one experiment, duplicate coverslips of adherent monocytes were subjected to trypsin and DNAase treatment identical to that experienced by glomerular cells. This resulted in counts of 1 and 2\% Ia-positive adherent monocytes. The lack of expression of Ia antigens by circulating monocytes has been observed in the mouse (D. I. Beller, personal communication). Although monocytes may have the capacity ultimately to express Ia, they apparently do so only as a more differentiated or activated cell. In any event, it is clear that even gross contamination by circulating mononuclear cells

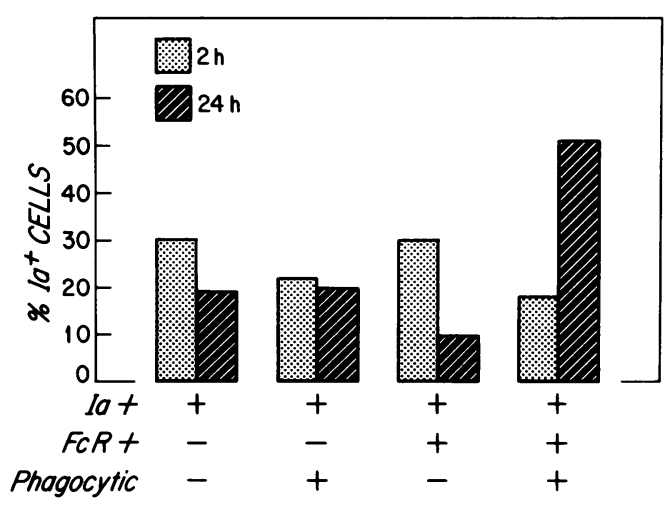

FIGURE 2 Division of adherent Ia-positive glomerular cells into functional categories, after 2 or $24 \mathrm{~h}$ in culture. $300 \mathrm{Ia}-$ positive cells were scored for demonstration of: (a) $\mathrm{Fc}_{\mathrm{c}}$ receptors $(\mathbf{F} \mathrm{CR}+$, defined as binding more than three EA); $(b)$ phagocytosis (defined as ingestion of more than three latex beads), both, or neither. The bars represent percentage of total adherent Ia-positive cells. 

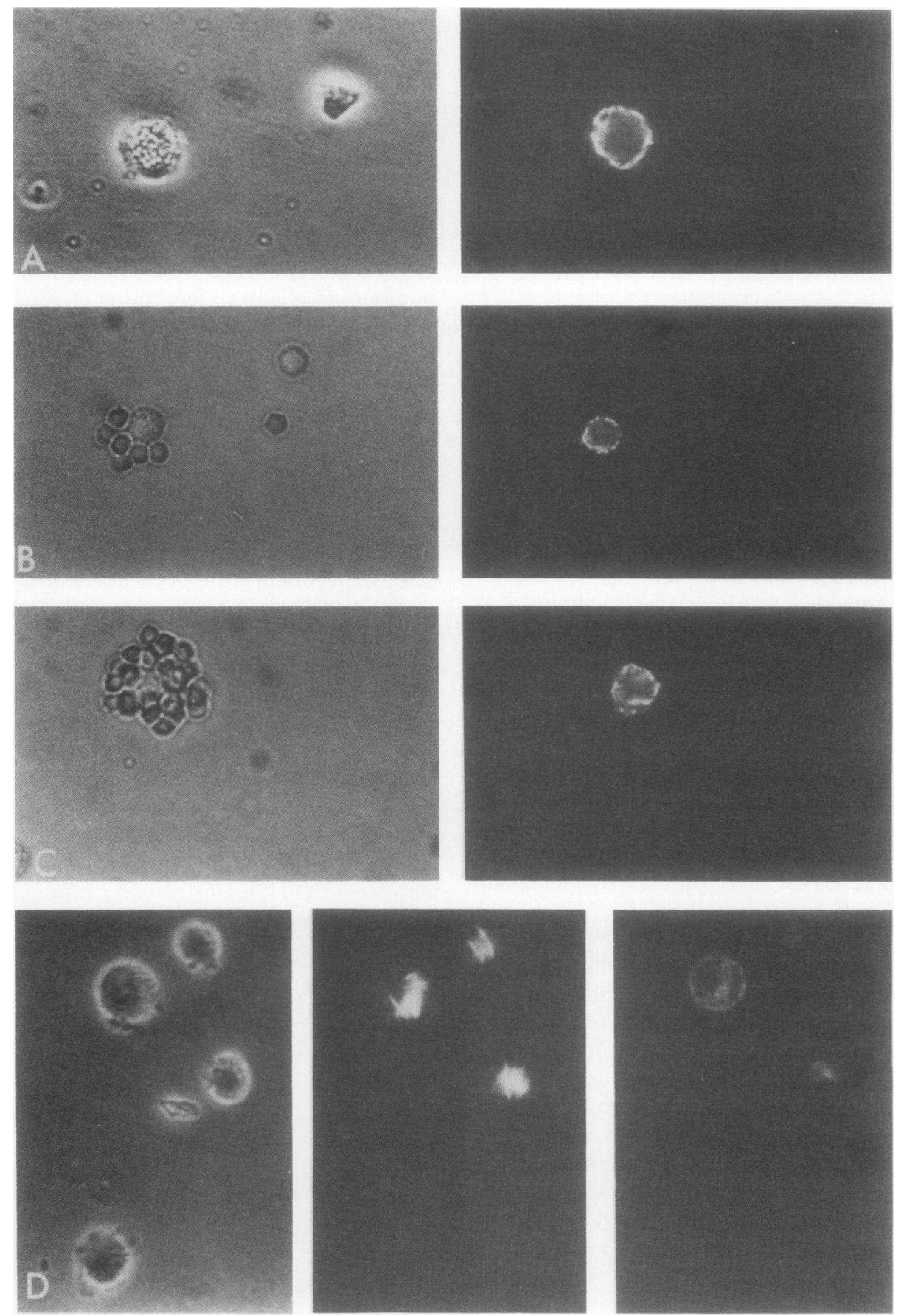

FIGURE 3 Phagocytosis and Fc receptor display by Ia-positive glomerular cells. (A) Phase contrast and fluorescent micrographs showing ingestion of a large number of latex beads by an Iapositive glomerular cell after $24 \mathrm{~h}$ of culture. Nearby is a smaller, nonphagocytic, Ia-negative endothelial cell, $\times 480$. (B) An EA-rosette by an adherent Ia-positive glomerular cell after $2 \mathrm{~h}$ of culture. The Ia-positive cells after $2 \mathrm{~h}$ of culture are somewhat smaller than after $24 \mathrm{~h}$ of culture, $\times 480$. (C) Increased binding of EA displayed by Ia-positive glomerular cells after overnight culture, $\times 480$. (D) Phase and fluorescent micrographs of adherent glomerular cells exposed to opsonized rhodamine-conjugated Listeria, allowed to phagocytose, and then labeled for Ia determinants with fluorescein-conjugated antibody. The middle panel demonstrates the rhodamine fluorescence of the three cells in the right corner, indicating phagocytosis. The end panel demonstrates the ring fluorescence of membrane Ia labeling on one of the phagocytic cells. 
cannot account for the high percentage of Ia-bearing cells isolated from the glomerulus.

In vivo phagocytosis by Ia-positive glomerular cells. To assess in vivo phagocytic function, we injected four Lewis rats with $8 \mathrm{mg}$ i.v. of rhodamine-conjugated heataggregated gamma globulin. The rats were sacrificed at $90 \mathrm{~min}$, at which time the labeled gamma globulin could be detected in isolated glomeruli. Harvesting the glomerular cells and then counterlabeling with fluorescein-labeled anti-Ia revealed the following: $30 \%$ of the adherent glomerular cells at $\mathbf{2} \mathrm{h}$ demonstrated rhodamine-fluorescent phagosomes, which indicates that they had ingested aggregated gamma globulin. $46 \%$ of all adherent Ia-positive cells were similarly labeled, making up $30 \%$ of all the phagocytic cells isolated from the glomerulus.

Immune function of glomerular cells. The presence of Ia antigens on phagocytic glomerular cells suggests these should be capable of presenting antigen to immune lymphocytes in a genetically restricted manner. We assessed antigen presentation with an assay based on immunity to Listeria monocytogenes (11). In this assay, immunized T lymphocytes are seen to proliferate in response to Listeria only when it is presented bound to Ia-positive, syngeneic phagocytes. Our initial attempts to induce adherent glomerular cells to present Listeria as an antigen failed. The explanation became clear from experiments elsewhere in our laboratory in which it was observed that trypsin removes from the cell membrane of phagocytes a binding protein for Listeria, thus preventing uptake (15). This protein is subsequently regenerated in culture (D. S. Weinberg and E. R. Unanue, experiments to be published). It should be noted that trypsin is used in the isolation procedure that precedes the establishment of glomerular cell cultures. Opsonization of the Listeria, however, allowed its uptake by way of the trypsin-resistant $F_{c}$ receptor. In one experiment, for example, opsonizing Listeria increased the percentage of Ia-positive, adherent glomerular cells ingesting Listeria from 3 to $37 \%$ (Fig. 3D).

Table III, therefore, demonstrates two experiments in which glomerular cells from Lewis rats were pulsed with opsonized heat-killed Listeria, washed, and then combined for $3 \mathrm{~d}$ in culture with $\mathrm{T}$ lymphocytes from Lewis rats immune to Listeria. Listeria-pulsed adherent glomerular cells were highly effective in presenting antigen to $T$ cells and inducing them to proliferate. The genetic restriction of this antigen presentation is demonstrated in Table IV, in which Lewis glomerular cells were far more effective in presenting antigen to sensitized lymphocytes of the

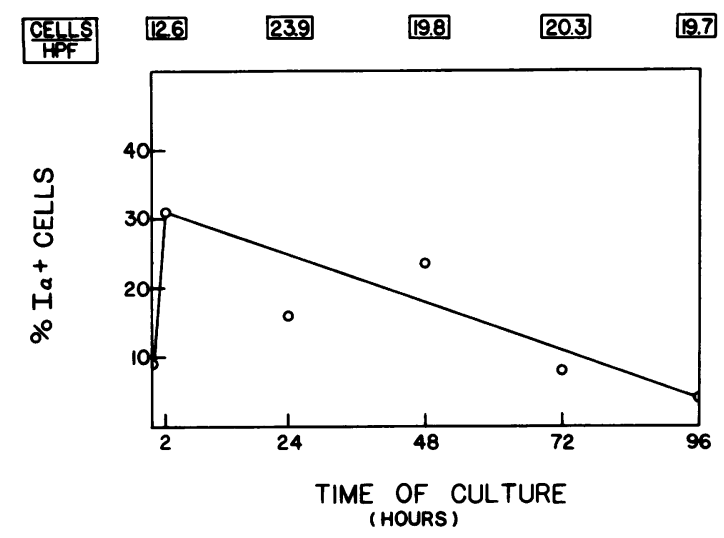

Figure 4 The percentage of total adherent glomerular cells displaying Ia determinants over time in culture. The percentage at time zero represents the total glomerular cell population that is Ia-positive before the adherence step. 200-300 cells were evaluated at each time period. In boxes at the top of the figure are the arithmetic mean number of total cells per high-power field $(n=25)$. The difference noted at 2 and $24 \mathrm{~h}$ is discussed in the text.

same haplotype than were comparably treated cells of the allogeneic Buffalo strain. The limited amount of lymphocyte reactivity seen when Lewis $T$ lymphocytes are mixed with Buffalo strain glomerular cells or peritoneal exudate cells, whether or not they have been pulsed with Listeria, appears to be due to early lymphocyte alloreactivity.

Finally, the glomerular cells are themselves extremely stimulatory to allogeneic lymphocytes in vitro (Table V). It is interesting to note that syngeneic glomerular cells were capable of inducing some degree of proliferation in lymphocytes, albeit to a much smaller extent than allogeneic stimulation.

\section{DISCUSSION}

We have identified in the rat a distinct, new glomerular cell population bearing Ia determinants that can actively function as an antigen-handling cell, capable of presenting antigen to $T$ lymphocytes in a genetically restricted manner. This glomerular cell type encompasses functionally heterogeneous subpopulations that are variably phagocytic and display $F c$ receptors and that can be enriched by their capacity for adherence. A labeling technique in which entire glomeruli can be made permeable to antibody has shown these cells to be intrinsic to the glomerulus. They are unevenly represented in glomeruli, ranging between 5 and 20 Ia-positive cells/glomerulus.

The other two cells are Ia-negative and somewhat smaller. The intense (red) fluorescence of the Listeria conjugate has caused some cross-excitation in the fluorescein (green) range despite the use of appropriate filters and barriers, $\times \mathbf{4 8 0}$. 

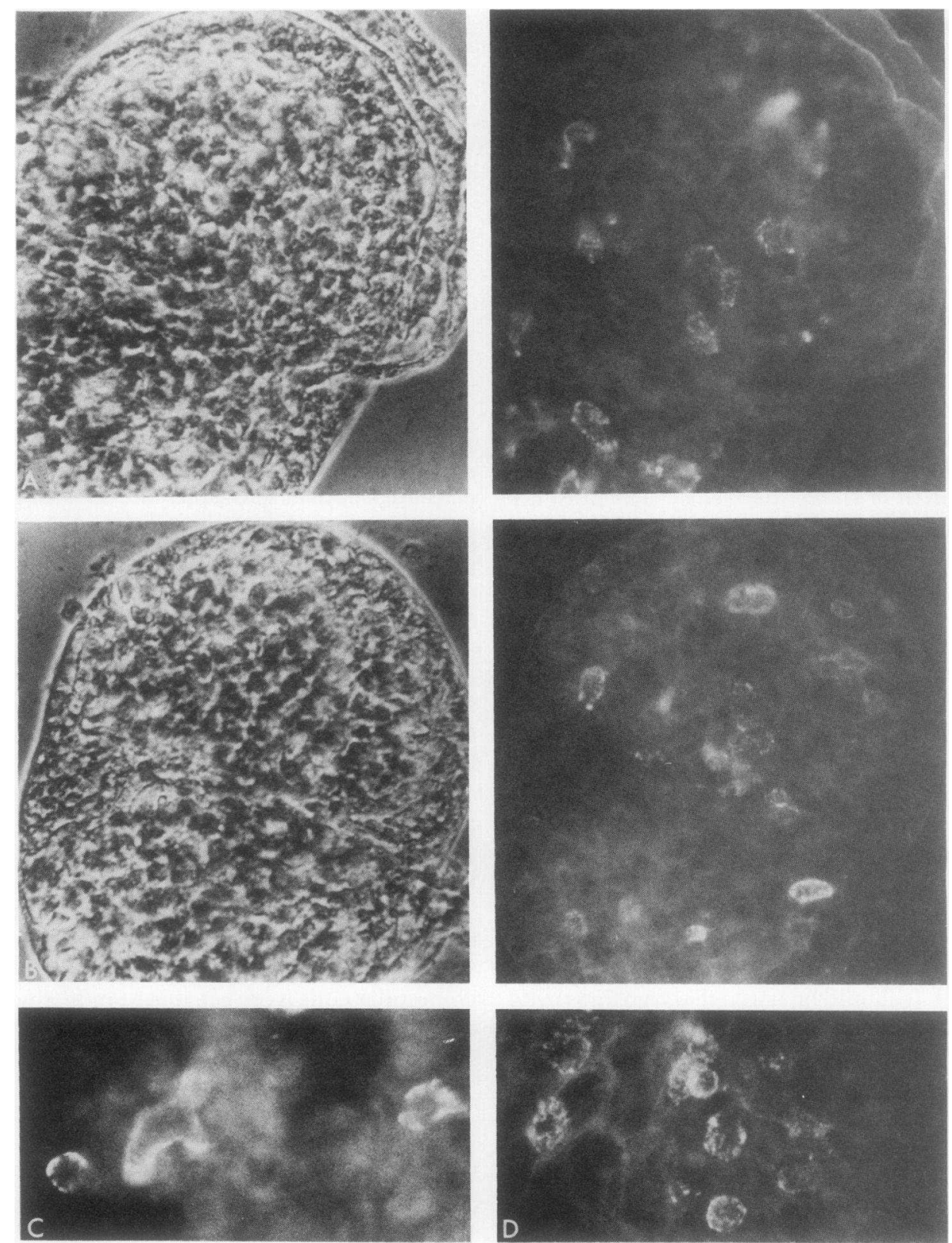

FIgURE 5 Phase and fluorescent micrographs of intact glomeruli permeable to anti-Ia antibody, as described in Methods. (A and B) Entire glomeruli showing the distribution of Ia-positive glomerular cells in situ. Glomerular stalks are seen on the right side. Note the varying positions of Ia-positive cells with a tendency toward axial distribution, $\times 240$. (C and D) Higher magnification of axial cells in other glomeruli revealing considerable heterogeneity of morphology of the Iapositive cells as they are sited in the glomerulus, ranging from ovoid to elongated, almost tortuous shapes, $\times 480$.

Although these cells comprise up to $8 \%$ of single-cell suspensions obtained from purified glomeruli, we suspect this is too high a proportion, perhaps because these cells are more easily released by enzymatic digestion than other glomerular cell types.
If one assumes $\sim 600$ cells in the average glomerulus of a 150- to 200-g rat (16), a range of 5 to 20 Ia-bearing cells per glomerulus yields a more realistic estimate that $1-2 \%$ of all glomerulus cells display Ia antigens on their surface. 
TABLE III

Proliferative Response of Sensitized Lymphocytes to Antigen Presentation by Glomerular Cells

\begin{tabular}{|c|c|c|c|c|}
\hline \multirow{2}{*}{$\begin{array}{l}\text { Lewis } \\
\text { T cells }\end{array}$} & \multirow{2}{*}{$\begin{array}{l}\text { Adherent } \\
\text { glomerular } \\
\text { cells }\end{array}$} & \multirow{2}{*}{$\begin{array}{c}\quad \text { Listeria } \\
\pm \quad \text { pulse }\end{array}$} & \multicolumn{2}{|c|}{$\left[\mathbf{H}^{3}\right]$ Thymidine incorporation ${ }^{*}$} \\
\hline & & & Experiment 1 & Experiment 2 \\
\hline+ & - & - & $130 \pm 29$ & $129 \pm 39$ \\
\hline- & + & - & $147 \pm 37$ & $135 \pm 20$ \\
\hline+ & - & + & $1,071 \pm 431$ & $4,926 \pm 1,760$ \\
\hline- & + & + & $102 \pm 25$ & $138 \pm 50$ \\
\hline+ & + & - & $1,266 \pm 312$ & $1,602 \pm 420$ \\
\hline \multirow[t]{2}{*}{+} & + & + & $51,084 \pm 2,767$ & $65,930 \pm 3,724$ \\
\hline & $\begin{array}{l}\text { Peritoneal } \\
\text { exudate } \\
\text { cells }\end{array}$ & $\pm \begin{array}{c}\text { Listeria } \\
\text { pulse }\end{array}$ & & \\
\hline - & + & - & $212 \pm 15$ & $118 \pm 9$ \\
\hline- & + & + & $101 \pm 53$ & $498 \pm 125$ \\
\hline+ & + & - & $898 \pm 338$ & $908 \pm 651$ \\
\hline+ & + & + & $28,377 \pm 8,160$ & $113,519 \pm 6,300$ \\
\hline
\end{tabular}

In both experiments, glomerular cells were cultured at $10^{5}$ cells/well for $2 \mathrm{~h}$ and the nonadherent cells removed. Some cultures were exposed to heat-killed, opsonized Listeria for $1 \mathrm{~h}$ at $37^{\circ} \mathrm{C}$ to permit phagocytosis; the cultures were subsequently extensively washed to remove unbound Listeria. Immune $\mathrm{T}$ lyphocytes were then added to the wells at a concentration of $4 \times 10^{5}$ cells $/$ well. Proliferation was assayed by tritiated thymidine incorporation after $4 \mathrm{~d}$ of culture. All points were measured in triplicate. As a positive control for antigen presentation, peritoneal exudate cells replaced adherent glomerular cells at a concentration of $10^{4}$ cells/well. Both lymphocytes and antigen-presenting cells were from Lewis strain rats.

* Arithmetic mean cpm $\pm \mathrm{SE}, n=3$.

It should be emphasized that these cells have been identified in well-perfused normal glomeruli and with minimal contamination by circulating cells. Further decreasing the possibility that these cells are simply circulating monocytes is our finding that, as in the mouse, $98-100 \%$ of circulating monocytes are Ianegative; thus, no degree of contamination could account for the high percentage of Ia cells that we have observed in adherent glomerular cell cultures. Both cell-suspension and glomerular-labeling experiments have indicated that this cell type resides to a major extent in the glomerulus. Finally, electron microscopic analysis of intact glomeruli using peroxidase-labeled antibodies has localized the Ia-positive cell to the mesangium in close proximity to Ia-negative typical mesangial cells. ${ }^{2}$ The Ia-positive cell is not, however, the predominant mesangial cell type, which in our cultures appears as an elongated, Ia-negative, nonphagocytic cell with spreading processes, as described by others in established cell lines (12).

Given that the Ia-positive cell is a normal resident of the glomerulus, there are two possible conjectures concerning its lineage. The first possibility is that it is inherently of renal origin, for which we have no direct proof or disproof. The second, which we favor on morphological grounds, is that it is ultimately derived from the bone marrow, belonging to the heterogeneous grouping of tissue-resident, mononuclear phagocytes that encompass Kuppfer cells, splenic and alveolar macrophages, etc. The bone marrow-derived monocytes may infiltrate the mesangium and reside in it for a period of time, acquiring properties of the more differentiated phagocyte. Its variability with respect to Fc receptor display, phagocytic capacity, and density of Ia antigens both at any one time and during sustained in vitro culture indicates that it may exist in the kidney in a variety of differentiated states. Precise definition of these issues is a subject of current investigation.

Why has this cell type resisted definition until this point? Certainly, isolated findings in previous investigations have pointed to the possible existence of such a cell. Two years ago Davies and Butcher (17) demonstrated that alloantisera against Ia antigens of the rat could be absorbed by homogenates prepared from perfused kidneys. Recently, Sakai et al. (18) have shown that unfractionated renal cells can weakly stimulate allogeneic lymphocytes in a mixed lymphocyte response assay. In long-term cultures derived from normal glomerular explants, Holdsworth et al. (19)

TABLE IV

Specificity of Antigen Presentation by Adherent Glomerular Cells to Sensitized Lymphocytes

\begin{tabular}{|c|c|c|c|c|}
\hline \multirow{3}{*}{$\begin{array}{l}\text { Lewis } \\
\mathrm{T} \text { cells }\end{array}$} & \multirow{3}{*}{$\begin{array}{c}\text { Listeria } \\
\text { pulse }\end{array}$} & \multicolumn{3}{|c|}{$\left[\mathrm{H}^{3}\right]$ Thymidine incorporation* } \\
\hline & & \multicolumn{3}{|c|}{ Antigen-presenting cells } \\
\hline & & None & Lewis & Buffalo \\
\hline+ & - & $311 \pm 259$ & & \\
\hline \multirow[t]{2}{*}{+} & + & $108 \pm 15$ & & \\
\hline & & \multicolumn{3}{|c|}{ Glomerular cells } \\
\hline- & - & & $196 \pm 18$ & $121 \pm 11$ \\
\hline- & + & & $358 \pm 103$ & $577 \pm 447$ \\
\hline+ & - & & $1,226 \pm 97$ & $2,724 \pm 303$ \\
\hline \multirow[t]{2}{*}{+} & + & & $34,121 \pm 2,809$ & $2,564 \pm 1,248$ \\
\hline & & \multicolumn{3}{|c|}{ Peritoneal exudate cells } \\
\hline- & - & & $105 \pm 19$ & $658 \pm 272$ \\
\hline- & + & & $220 \pm 86$ & $43 \pm 3$ \\
\hline+ & - & & $131 \pm 23$ & $6,989 \pm 742$ \\
\hline+ & + & & $43,705 \pm 4,885$ & $14,100 \pm 726$ \\
\hline
\end{tabular}

Experimental conditions were the same as in Table III. Antigen-presenting phagocytes were from either the Lewis or Buffalo strain rats. Sensitized T cells were Lewis strain. * Arithmetic mean cpm $\pm \mathrm{SE}, n=3$. 
TABLE V

Stimulation of Lymphocytes in Mixed Cultures

\begin{tabular}{lcc}
\hline \multicolumn{1}{c}{ Stimulator cells } & $\begin{array}{c}\text { Responder } \\
\text { lymphocytes } \\
\text { (Buffalo) }\end{array}$ & $\begin{array}{c}\text { H'}^{\text {-Thymidine }} \\
\text { incorporation* }^{*}\end{array}$ \\
\hline None & + & $289 \pm 49$ \\
Lewis spleen cells & - & $1,176 \pm 568$ \\
Lewis spleen cells & + & $67,561 \pm 13,719$ \\
Lewis glomerular cells & - & $149 \pm 11$ \\
Lewis glomerular cells & + & $33,456 \pm 2,433$ \\
Buffalo glomerular cells & - & $352 \pm 251$ \\
Buffalo glomerular cells & + & $3,226 \pm 1,122$ \\
\hline
\end{tabular}

Stimulator cells consisted of: $(a)$ adherent Lewis spleen cells at $2 \times 10^{5} /$ well, $(b)$ adherent Lewis glomerular cells at $5 \times 10^{5}$ cells/well, or $(c)$ adherent Buffalo glomerular cells at $5 \times 10^{5}$ cells/well. Stimulator cells were allowed to adhere to culture for $2 \mathrm{~h}$, washed, and then irradiated with 1,500 rad. Allogeneic responder lymphocytes (Buffalo strain) were then added to the cultures at $2 \times 10^{5} /$ well. Proliferation of responder lymphocytes was assessed by measuring tritiated thymidine incorporation after $6 \mathrm{~d}$ of co-culture. All points were measured in triplicate.

* Arithmetic mean cpm $\pm \mathrm{SE}, n=3$.

observed a very rare cell in the outgrowing cell population, $10-20 \mu \mathrm{m}$ in diameter, that resembled mononuclear cells. Camazine et al. (6) observed a phagocytic cell in short-term cultures of isolated glomerular cells that developed $\mathrm{Fc}$ receptors in prolonged culture. In the above studies, functional assays or localization of the cell were not done; nor was the presence of contaminating monocytes ruled out, a contention that has served as the prevalent explanation for the presence of such cells $(19,20)$.

Indeed, one review (20) has suggested that there is no evidence that mononuclear phagocytes are present in the mesangium in the absence of monocytic infiltrates induced by an inflammatory deposit such as immune complexes. Thus, in evaluating female human kidneys transplanted into males, Schiffer and Michael (21) could not find Y-body-containing cells in the transplanted kidney. After transplanting bone marrow cells with distinctive lysosomal markers into syngeneic mice, Striker et al. (22), using electron microscopy, observed phagocytosis in the glomerulus only by acutely infiltrating monocytes $24 \mathrm{~h}$ after injecting immune complexes intravenously. Although further investigation is required to explain the discrepancy between the above observations and our delineation of glomerular phagocytes, we believe a key issue will be the methodologic problems of sampling attendant to histochemical and ultrastructural analysis in the detection of a small phagocytic subpopulation totaling
$1-2 \%$ of glomerular cells. Our approach has allowed detection of as few as 5 cells/glomerulus. Our conclusions that the phagocytic cell described in the report is normally resident in the glomerulus is consistent with previous reports of in situ phagocytosis of noninflammatory substances including ferritin (23), colloidal carbon (24), and thorium (25).

The display of Ia determinants by a residential glomerular cell bears particular relevance to the subject of renal allograft and rejection. Disparity between donor and host across the I region of the major histocompatibility complex is essential to the induction of host lymphocyte immunity. With the assumption that the kidney does not display intrinsic Ia determinants, previous research devoted to abrogating the induction phase of host immunity has attempted to eliminate from the graft passenger leukocytes, the only hypothesized source of $\mathrm{Ia}(26)$. The relative lack of success with this approach, together with our finding an extremely vigorous mixed leukocyte reaction by allogeneic lymphocytes to Ia-positive glomerular cells, indicates that the mononuclear mesangial phagocyte might be the proper focus of future investigation into this issue.

Finally, the observations in this report potentially suggest reconsideration of the contributions of various immune mechanisms to glomerular inflammation. Only recently has the participation of circulating monocytes in experimental glomerulonephritis been delineated $(3,22)$, and the stimulus causing their infiltration remains obscure, except for the finding that it is not complement dependent (27). The existence of an immanent, mononuclear phagocyte bearing Ia determinants in the glomerulus enlarges the role immune cells may play in initiating or sustaining, via recruitment of additional cells, an immune reaction in the kidney. Considerable evidence has accumulated over the last decade emphasizing the pivotal position occupied by Ia-bearing phagocytes in immunological cellular interactions (28). They degrade and process antigen to selectively initiate cellular and humoral immune responses by lymphocytes. They concomitantly engage in reciprocal, modulatory interactions with lymphocytes that effect proliferation, differentiation, factor secretion, and other functions. We are currently investigating the function of this glomerular cell type in the context of such interchanges, with the additional consideration that the nonimmunological function of the glomerulus may also be affected by such interactions.

\section{ACKNOWLEDGMENTS}

We thank Barbara K. Teixeira for her efforts in preparing this manuscript, Anthony Merola and Robert Rubin for photographic assistance, and Melanie McGrory for excellent technical assistance. 


\section{REFERENCES}

1. Unanue, E. R., and F. J. Dixon. 1967. Experimental glomerulonephritis: immunological events and pathogenetic mechanisms. Adv. Immunol. 6: 1-90.

2. Cochrane, C. G., E. R. Unanue, and F. J. Dixon. 1965. A role of polymorphonuclear leukocytes and complement in nephrotoxic nephritis. J. Exp. Med. 122: 99-119.

3. Schreiner, G. F., R. S. Cotran, V. Pardo, and E. R. Unanue. 1978. A mononuclear cell component in experimental immunological glomerulonephritis. J. Exp. Med. 147. 369-384.

4. Griffith, L. D., R. E. Bulger, and B. F. Trump. 1967. The ultrastructure of the functioning kidney. Lab. Invest. 16: $220-231$.

5. Burlington, H., and E. P. Cronkite. 1973. Characteristics of cell cultures derived from renal glomeruli. Proc. Soc. Exp. Biol. Med. 142: 143-149.

6. Camazine, S., G. Ryan, E. R. Unanue, and M. J. Karnovsky. 1976. Isolation of phagocytic cells from the rat renal glomerulus. Lab. Invest. 35: 315-326.

7. Williams, A., G. Gulfre, and C. Milstein. 1977. Analysis of cell surfaces by xenogeneic myeloma-hybrid antibodies: differentiation antigens of rat lymphocytes. Cell. 12: 663-673.

8. McMaster, W. R., and A. F. Williams. 1979. Identification of Ia glycoproteins in rat thymus and purification from rat spleen. Eur. J. Immunol. 9: 426-433.

9. Cowing, C., B. C. Schwartz, and H. Dickler. 1979. Macrophage Ia antigens. I. Macrophage populations differ in their expression of Ia antigens. J. Immunol. 120: $378-384$.

10. Beller, D. I., J-M. Kiely, and E. R. Unanue. 1980. Regulation of macrophage populations. I. Preferential induction of Ia-rich peritoneal exudates by immunologic stimuli. J. Immunol. 124: 1426-1432.

11. Farr, A. G., J-M. Kiely, and E. R. Unanue. 1979. Macrophage-T cell interactions involving Listeria monocytogenes - role of the H-2 gene complex. J. Immunol. 122 . 2395-2404.

12. Ausiello, D., J. Kreisberg, C. Roy, and M. Karnovsky. 1980. Contraction of cultured rat glomerular cells of apparent mesangial origin after stimulation with Angiotensin II and arginine vasopressin. J. Clin. Invest. 65: 754-760.

13. Steinman, R., N. Nogueira, M. Witmer, J. Tydings, and I. Mellman. 1980. Lymphocyte enhances the expression and synthesis of Ia antigens on cultured mouse peritoneal macrophages. J. Exp. Med. 152: 1248-1255.

14. Beller, D. I., and E. R. Unanue. 1981. Regulation of macrophage populations. II. Synthesis and expression of Ia antigens by peritoneal exudate macrophages is a transient event. J. Immunol. 126: 263-269.
15. Weinberg, D. S., and E. R. Unanue. 1981. Antigenpresenting function of alveolar macrophages: uptake and presentation of Listeria monocytogenes. J. Immunol. 126: 794-799.

16. Olivetti, G., P. Anversa, M. Melissari, and A. V. Loud. 1980. Morphometry of the renal corpuscle during postnatal growth and compensatory hypertrophy. Kidney Int. 17: 438-444.

17. Davies, H., and G. Butcher. 1978. Kidney alloantigens determined by two regions of the rat major histocompatibility locus. Immunogenetics. 6: 171-181.

18. Sakai, A., K. Yakushiji, and S. Mashimo. 1980. Lymphocyte stimulation by allogeneic tissue cells and in rats: with special reference to differential survival of skin and kidney allografts. Transplant. Proc. 12: 74-81.

19. Holdsworth, S. R., E. F. Glasgow, R. C. Atkins, and N. M. Thomson. 1978. Cell characteristics of cultured glomeruli from different animal species. Nephron. 22: 454-459.

20. Michael A. F., W. F. Keene, L. Raij, R. Vernier, and S. Mauer. 1980. The glomerular mesangium. Kidney Int. 17: 141-154.

21. Schiffer, M. S., and A. F. Michael. 1978. Renal cell turnover by Y-chromosome (Y-body) staining of the transplanted human kidney. J. Lab. Clin. Med. 92: 841-848.

22. Striker, G. E., M. Mannik, and M. Tung. 1979. Role of marrow-derived monocytes and mesangial cells in removal of immune complexes from renal glomeruli. J. Exp. Med. 149: 127-136.

23. Farquar, M. G., and G. E. Palade. 1962. Functional evidence for the existence of a third cell type in the renal glomerulus. J. Cell Biol. 13: 55-87.

24. Elema, J. D., J. R. Hoyer, and R. L. Vernier. 1976. The glomerular mesangium: uptake and transport of intravenously injected colloidal carbon in rats. Kidney Int. 9: 394-406.

25. Latta, H., and A. B. Mannsbach. 1962. Relationship of the centrilobular region of the glomerulus to the juxtaglomerular apparatus. J. Ultrastruct. Res. 6: 562-578.

26. Stuart, F. P., E. Bastien, A. Holter, F. W. Fitch, and W. L. Elkins. 1971. The role of passenger leukocytes in the regulation of renal allografts. Transplant. Proc. 3: 461-464.

27. Unanue, E. R., G. F. Schreiner, and R. S. Cotran. 1981. A role of mononuclear phagocytes in immunologically induced glomerulonephritis. In Immune Mechanisms in Renal Disease. A. Michael and N. Cummings, editors. In press.

28. Unanue, E. R. 1981. The regulatory role of macrophages in antigenic stimulation. II. Symbiotic relationship between lymphocytes and macrophages. Adv. Immunol. 31: $1-136$. 